\title{
Holocene distribution of Octodontid rodents in central Chile
}

\author{
Distribución holocénica de roedores octodóntidos en Chile central
}

\author{
BÁRBARA SAAVEDRA \& JAVIER A. SIMONETTI
}

Departamento de Ciencias Ecológicas, Facultad de Ciencias, Universidad de Chile, Casilla 653, Santiago, Chile; e-mail: bsaavedr@icaro.dic.uchile.cl

\begin{abstract}
We describe the Holocene distribution of the Octodontids Aconaemys fuscus, Octodon bridgesi, O. degus, O. lunatus, O. pacificus and Spalacopus cyanus from Central Chile. We compared ancient and present day ranges. The Holocene pattern was inferred from zooarchaeological records. Octodon degus, O. lunatus, O. bridgesi, and Aconaemys fuscus showed a reduction in their geographic range. Although specific mechanisms remain to be tested, human disturbance seems to be the distal factor that explains the reduction of ranges for some taxa.
\end{abstract}

Key words: Octodontidae, Holocene, central Chile, zooarchaeology.

\section{RESUMEN}

Describimos la distribución holocénica de los roedores octodóntidos Aconaemys fuscus, Octodon bridgesi, O. degus, O. lunatus, O. pacificus y Spalacopus cyanus en Chile central, y la comparamos con su distribución actual. El patrón de distribución holocénico se infirió de registros zooarqueológicos. Octodon degus, O. lunatus, O. bridgesi y Aconaemys fuscus muestran una reducción en su rango geográfico. A pesar de que los mecanismos específicos que explican este patrón permanecen sin ser resueltos, la perturbación humana parece ser el factor distal que explicaría la reducción en el rango de distribución para algunas de estas especies.

Palabras clave: Octodontidae, Holoceno, Chile central, zooarqueología.

\section{INTRODUCTION}

Octodontids represent a conspicuous group among Chilean rodents (Contreras et al. 1987, Gallardo \& Kirsch 2001). As a result of a long evolutionary history in southern South America, this taxon gathers 11 endemic species, six of which occupy central Chile, all herbivores: Aconaemys fuscus, Octodon bridgesi, O. degus, O. lunatus, O. pacificus and Spalacopus cyanus. These taxa are currently distributed from $27^{\circ}$ to $38^{\circ} \mathrm{S}$, mostly in the Mediterranean region of Chile (Contreras et al. 1987). Octodontids use different habitats, like $O$. lunatus and $O$. bridgesi that inhabit dense vegetation, or $O$. degus that prefer more open shrublands (Contreras et al. 1987, Simonetti 1989a, Muñoz-Pedreros 2000). Despite being a comparatively well known group, several aspects of their ecology and distribution remain unresolved, a fact reflected in the wealth of new records of these taxa (e.g., Hutterer 1994, Podestá et al. 2000, Díaz et al. 2002). The state of knowledge is even worse for paleoecology, where scarce knowledge of past distribution and abundance of Octodontids exists (Simonetti 2000).

Human activities might indeed have affected population's persistence of several Octodontid species, determining local extinction in late Holocene and historical times. Octodon bridgesi for example, disappeared from Andean range in central Chile due to habitat clearance for horticultural development (Simonetti 1989a). It also went extinct in the coastal range due to local intensification of agriculture in areas previously unused by local farmers (Simonetti $\&$ Saavedra 1998). The current absence of $O$. bridgesi in north-central Chile was then 
achieved only recently, as a result of local extinction driven by human activities.

Changes in geographic distribution have been also reported for other Octodontids. Aconaemys fuscus, currently confined to the southern Andes, ca. 1,000 years ago inhabited areas close to Santiago, more than $100 \mathrm{~km}$ north of its current distribution (Simonetti \& Saavedra 1994). On the same vein, O. lunatus and $O$. degus, currently restricted to central Chile, were found at least $50 \mathrm{~km}$ south of their current distribution in archaeological sites dated 1,000 years old (Saavedra et al. 1991).

Evidence suggests that present-day distribution for Octodontids was achieved recently. As new information is available, here we describe the Holocene distribution of Octodontid in central Chile, based on published and new zooarchaeological records, aiming to illustrate their geographic range dynamics.

\section{MATERIAL AND METHODS}

Holocene distribution was inferred for the six octodontid species that currently inhabit central Chile: Octodon bridgesi, O. degus, O. lunatus, O. pacificus, Aconaemys fuscus and Spalacopus cyanus. Distribution was inferred based on zooarchaeological composition of 12 new, and seven published archaeological sites (Saavedra et al. 1991, 2003, Simonetti 1994, Simonetti \& Saavedra 1994, 1998). All sites were excavated using regular archaeological methods, and rodent analysis was made based on usual identification keys (e.g., Reise 1973, Pearson 1995), as well as comparison with voucher specimens deposited in museums and collections. Sites were arranged in seven areas, from Huentelauquén in the north, to Isla Mocha in the south (Fig. 1). When more than one site was analyzed in an area, all were located within a range of $5 \mathrm{~km}$ for the area. For each site, we recorded Octodontid composition. Due to the scarcity of zooarchaeological records, we also included information regarding other caviomorphs found in new sites, although those data were not analyzed here.

New zooarchaeological information was recovered from: (A) Huentelauquén $\left(31^{\circ} 38^{\prime} \mathrm{S}\right.$, $71^{\circ} 33^{\prime}$ W, Fig. 1). Here we report the zooarchaeological content of site " 04 . Mi. Hue. 2". This is an Early Holocene site dated 9,110 8,800 years BP (Weisner et al. 2000), where 2,962 bone remains were retrieved. From these, $752(25.4 \%)$ were small mammals that we classified as the following taxa: Abrocoma bennetti, Lagidium viscacia, Octodon degus, O.

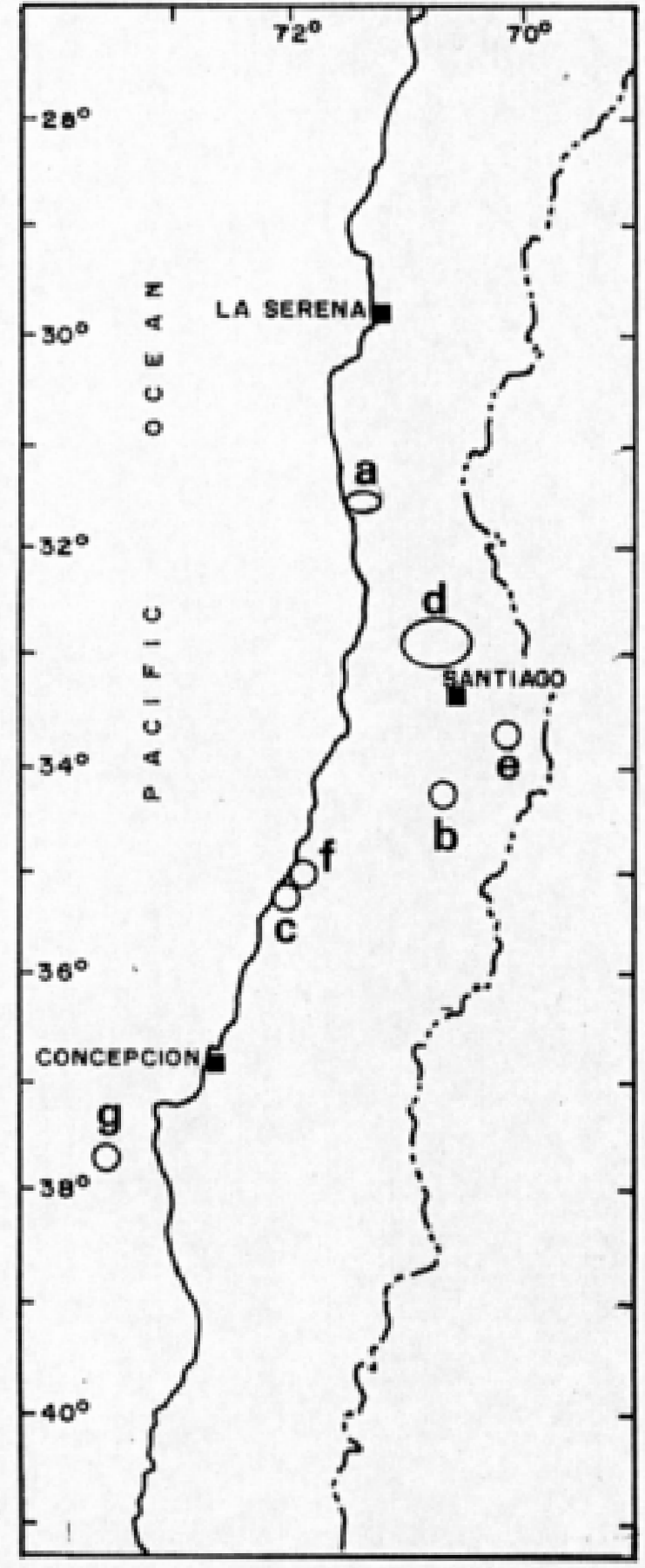

Fig. 1: Geographic localization of archaeological areas included in this analysis. Letters are: (a) Huentelauquén, (b) La Granja, (c) Chanco, (d) Cordón de Chacabuco, (e) El Manzano, (f) Quivolgo, and (g) Isla Mocha.

Localización geográfica de áreas arqueológicas incluidas en este análisis. Las letras son: (a) Huentelauquén, (b) La Granja, (c) Chanco, (d) Cordón de Chacabuco, (e) El Manzano, (f) Quivolgo e (g) Isla Mocha. 
lunatus, and Spalacopus cyanus; (B) La Granja (34 $24^{\prime}$ S, $\left.71^{\circ} 11^{\prime} \mathrm{W}\right)$, located $100 \mathrm{~km}$ south of Santiago (Fig. 1). Bone material was recovered from three archaeological sites: "La Granja 1", "La Granja 2", and "La Granja 3", excavated during 1993-1995 (Planella \& Tagle 1998). These sites dated in 1,400-975 years BP. A total of 5,249 bone specimens were recovered, comprising 1,928 rodents $(36.7 \%)$, of the species A. bennetti, A. fuscus, Myocastor coypus, O. degus, and S. cyanus; and (C) Chanco $\left(35^{\circ} 43^{\prime} \mathrm{S}, 72^{\circ} 29^{\prime} \mathrm{W}\right)$ is a coastal area in the southern margin of the Mediterranean zone (Fig. 1). Three sites were analyzed: "Punta La Gaviota", "Cerro Las Conchas", and "Conchal Valenzuela", dated in 5,685-500 years BP (Gaete et al. 1992, Gaete \& Sánchez 1993, Sánchez \& Gaete 1993). A total of 474 bone specimens contained $128(27 \%)$ rodents. The species found here were: A. bennetti, A. fuscus, and M. coypus.

Among published zooarchaeological records we included: (D) Cordón de Chacabuco, located $70 \mathrm{~km}$ north of Santiago (32 $59^{\prime} \mathrm{S}$, $70^{\circ} 42^{\prime}$ W, Fig. 1). Here, five archaeological sites were excavated: "Las Chilcas 1", "Las Chilcas 2", "Piedra El Indio", "El Carrizo", and "La Nogalada" (Hermosilla \& Saavedra 2000), dated 2,830 to 160 years BP. Octodontids included A. fuscus, O. bridgesi, O. degus, O. lunatus, and S. cyanus; (E) El Manzano (33 ${ }^{\circ} 16^{\prime}$ $\left.\mathrm{S}, 70^{\circ} 37^{\prime} \mathrm{W}\right)$, located in the Andean range close to Santiago (Fig. 1), where two archaeological sites ("La Batea 1" and "El Manzano 1") were excavated (Simonetti 1989a, 1994, Saavedra et al. 1991, Simonetti \& Saavedra 1994). These sites have a chronology from 8,900 up to ca. 500 years BP. Octodontids recorded were A. fuscus, O. bridgesi, O. degus, O. lunatus, and S. cyanus; (F) Quivolgo ( $35^{\circ} 19^{\prime}$ S, $71^{\circ} 24^{\prime}$ W), a coastal location at the mouth of Maule River, where the site "07Co24" was excavated (Saavedra et al. 1991, Simonetti 1994, Fig. 1). Here five Octodontids were recognized: A. fuscus, O. bridgesi, O. degus, O. lunatus, and S. cyanus; (G) Isla Mocha, is the single off-continental area analyzed $\left(38^{\circ} 22^{\prime} \mathrm{S}\right.$, 733' W, Fig. 1). Four sites were excavated: "P5-1", "P22-1", "P25-1", and "P31-1". Octodon pacificus was the only Octodontid found in these remains (Quiroz \& Sánchez 1993, Saavedra et al. 2003).

Zooarchaeological remains covered almost all the Holocene, including sites from early Holocene (e.g., Huentelauquén: ca. 9,000-8,000 years BP), to late Holocene (e.g., La Granja 1: ca. 1,200-500 AD), as well as recent historical times (e.g., Piedra El Indio: ca. 500 years BP).
Length of human occupation varied among sites, ranging from 7,400 years (e.g., El Manzano 1), to less than 300 years (e.g., La Granja and Isla Mocha sites). To pursue our analysis, only presence/absence of a taxon was considered, ignoring changes in abundance (Reitz \& Wing 1999).

\section{RESULTS}

Six Octodontids were recorded during the Holocene in central Chile. Although the same species are observed today in the area, significant reductions in geographic range were detected for four of these taxa. Octodon degus, currently the most abundant Chilean caviomorph, showed an extended latitudinal range in ancient time (Fig. 2). Until 1,000 years $\mathrm{BP}$, its southern limit was found in Quivolgo, extending its current distribution ca. $50 \mathrm{~km}$ south. Octodon lunatus was also found in this site, ca. $155 \mathrm{~km}$ south of its present distribution, representing a change of at least two degrees south during Holocene (Fig. 2). Octodon lunatus was present in Quivolgo at least until ca. 1,000 years BP (Saavedra et al. 1991). This species is now restricted to the coastal range of central Chile from Fray Jorge $\left(30^{\circ} 39^{\prime} \mathrm{S}, 71^{\circ} 40^{\prime} \mathrm{W}\right)$ to Quilpué $\left(33^{\circ} 03^{\prime} \mathrm{S}\right.$, $\left.71^{\circ} 26^{\prime} \mathrm{W}\right)$, and in the Andes close to Santiago

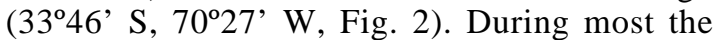
Holocene, $O$. bridgesi reached up to $33^{\circ} \mathrm{S}$, and was recorded in El Manzano, Las Chilcas and La Granja (Fig. 2). Currently, O. bridgesi is restricted to the southern portion of central Chile, depicting a reduction of $100 \mathrm{~km}$ in their northern range. Finally, the presence of $O$. pacificus in all archaeological sites analyzed in Isla Mocha, indicates its presence in the island during Holocene.

Changes in distribution also modified sympatry patterns among Octodontid species. Octodon degus and O. bridgesi overlapped during the Holocene. Co-occurrence was observed in six out of 19 archaeological sites. Octodon lunatus and O. bridgesi also cooccurred during the Holocene, and were found together in six sites. The archaeological coexistence of the three continental Octodon species was acknowledged for the first time in Quivolgo (Saavedra et al. 1991). Currently, $O$. degus and $O$. bridgesi, as well as O. lunatus and $O$. bridgesi are allopatric species (Contreras et al. 1987).

Aconaemys fuscus also showed a significant range reduction in their northern distribution during Holocene. During early 
Holocene, A. fuscus occupied Andean areas close to Santiago, along with coastal sectors of the Maule River (Fig. 2). This species was also found in Tagua-Tagua records $\left(34^{\circ} 30^{\prime} \mathrm{S}\right.$, $\left.71^{\circ} 10^{\prime} \mathrm{W}\right)$, dated ca. 10.000 years BP (Simonetti 1989b). Currently, A. fuscus is mostly confined to southern Andes from Curicó to Temuco $\left(38^{\circ} 44^{\prime} \mathrm{S}, 7^{\circ} 35^{\prime} \mathrm{W}\right)$, reaching the coast near Concepción. Our findings imply a reduction of ca. $120 \mathrm{~km}$ in its northern limit.
Spalacopus cyanus did not show modification in its distribution range when comparing ancient and present day distribution (Fig. 3). During Holocene, S. cyanus was distributed from Huentelauquén to Quivolgo along the coast, and in the Andean portion near Santiago. The same distribution is observed today for the species (Fig. $3)$. Stratigraphical co-occurrence of A. fuscus and $S$. cyanus was observed in six out of 19 sites. No coexistence is observed today for these species (Contreras et al. 1987).
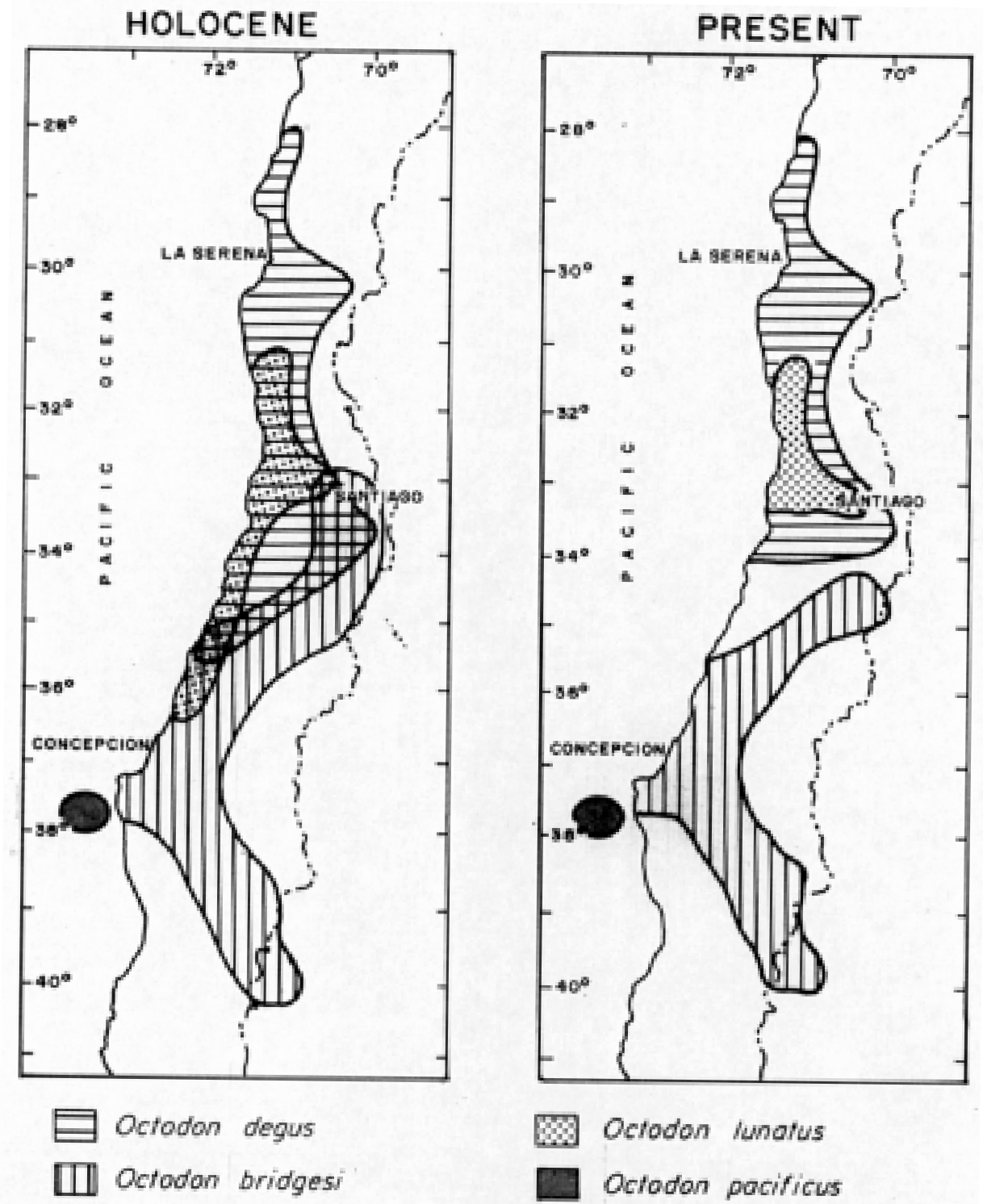

Fig. 2: Holocene and present distribution of Octodon bridgesi, O. degus, O. lunatus, and O. pacificus in central Chile, inferred from zooarchaeological and literature survey, respectively.

Distribución Holocénica y Presente de Octodon bridgesi, O. degus, O. lunatus y O. pacificus en Chile central, inferidas a partir del análisis zooarqueológico y de revisión de literatura, respectivamente. 


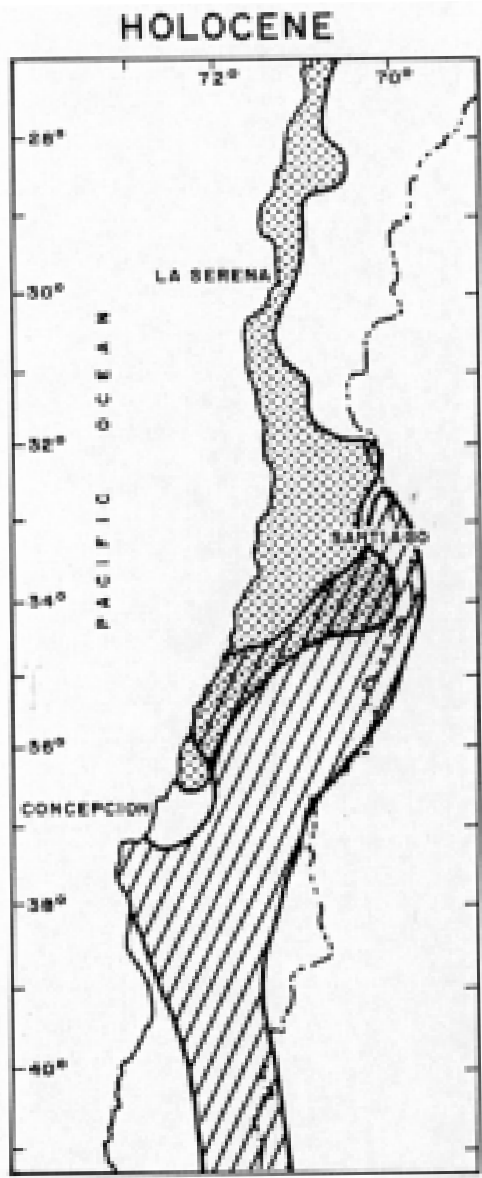

Spolocopus cyanus

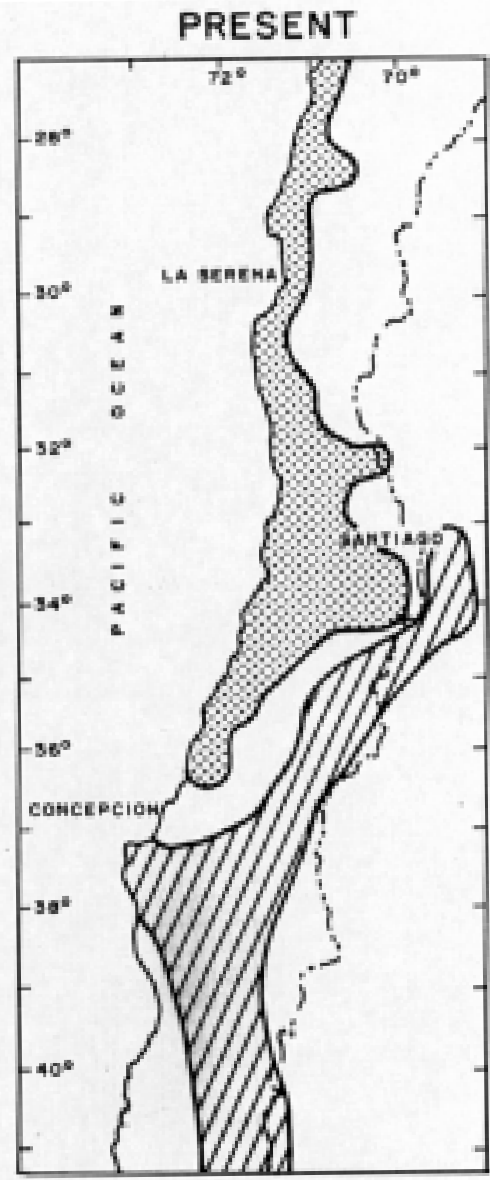

DD Aconoemys fuscus

Fig. 3: Holocene and present distribution of Aconaemys fuscus and Spalacopus cyanus in central Chile inferred from zooarchaeological and literature survey, respectively.

Distribución Holocénica y Presente de Aconaemys fuscus y Spalacopus cyanus en Chile central, inferidas a partir del análisis zooarqueológico y de revisión de literatura, respectivamente.

\section{DISCUSSION}

Four out of six Octodontid species showed reductions in their geographical range in the recent past in central Chile. Human activities have been suggested as the major cause of local extinction of $O$. bridgesi in the Andes and in the coastal range close to Santiago (Simonetti 1989a, Simonetti \& Saavedra 1998). In the Andes of central Chile, local horticulturalist reduced vegetation cover ca. 1,500 years ago to obtain agricultural lands, determining the disappearance of $O$. bridgesi, a dense vegetation specialist, from the area (Simonetti 1989a). The same habitat reduction was driven in the coastal range of central Chile ca. 200 years ago, due to the development of intense wood cutting and wheat production, triggering the local extinction of this taxon (Simonetti \& Saavedra 1998). Local extinction in the Andean sites was preceded by changes in the relative abundance of the generalist Octodon degus and O. bridgesi in stratigraphical (i.e., temporal) sequences. While $O$. degus became progressively more abundant in recent times, $O$. bridgesi became scanty, coupled to the historical reduction of vegetative cover (Simonetti 1989a).

Although central Chile has been characterized by a long history of human presence (Aschmann 1991), local extinction observed for other Octodontid species can not be directly associated to human disturbance. Octodon degus for example, uses preferentially habitats with low vegetation cover, being 
regularly found in human-modified habitats (Mann 1978, Meserve et al. 1984). Based on habitat preferences, $O$. degus should have been favored by human-induced changes in habitat cover (Simonetti 1989a). Nevertheless, O. degus showed a reduction in its southern limit, where elevated human disturbance has been also recognized (Miller 1980). Interestingly, $A$. fuscus experienced range reduction during Holocene. Due to its fossorial habits, habitat destruction by domestic cattle has been advanced as a causal factor to explain its range reduction (Muñoz-Pedreros 2000). Nevertheless, $S$. cyanus is also a fossorial taxon that was not affected in their geographic range, suggesting that human activities do not have equivalent effects on the persistence of different species.

Factors like climate seem not to be important in explaining the ancient rodent dynamics shown here, since the changes in distributional range occurred in the last 1,500 years, where no significant alterations in climate are registered (Villagrán \& Varela 1990, Villagrán 1994). Nevertheless, the occurrence of other significant climate changes like Pleistocene glaciations (Villagrán 1984) might probable have affected rodent distribution at the beginning of the Holocene, and their study must be accomplished to complete the Holocene history of this group. Likewise, due to methodological limitations imposed by zooarchaeological analysis (Rosen 1988, Reitz \& Wing 1999) changes in Octodontid distribution advanced by us should be regarded as hypothesis. Particularly, the ancient distributions proposed for these rodents must be considered as the minimum distributional range observed for Octodontid species in the past. The fact that they are based on the manifest presence of the taxon in a site, does not prevent the extension of ranges if other records are registered in new archaeological sites.

Geographic reduction of Octodontids occurred in all cases due to extinction of peripheral populations: southern limit for $O$. degus and $O$. lunatus, and northern limit for $O$. bridgesi and $A$. fuscus. This may be explained based on small population size and non-optimal habitats associated to marginal populations (Brown 1984). Information regarding current distribution of populations, along with local abundance, may be useful to explain historical changes in range reduction. Moreover, since five out of the six Octodontids analyzed here are of conservation concern (Miller et al. 1983), understanding historical range reduction may be useful for the designing of management practices.
Timber extraction, forestry, or live stock grazing has been developed in central Chile more intensively than in other area of the country (Miller 1980). Other human-induced disturbances like introduction of exotic predators and competitors like black rat (Rattus rattus), rabbits (Oryctolagus cuniculus), or goats (Capra hircus), might also have negative effects on native octodontids (Simonetti 1983, Jaksic 1998). Introduced goats for example reduced vegetation cover by consuming native vegetation. This reduction favors the presence of rabbits, which also feed on native vegetation, reducing overall food and habitat resources for native species like $O$. degus, and probably reducing its abundance (Simonetti 1983).

Holocene records for Octodontids evidence the elevated dynamism of Chilean rodent assemblages, indicating that present-day patterns of rodent distribution have been achieved very recently. This fact must be acknowledged when faunal analyses are made. For example when comparing Mediterranean areas, small mammals of central Chile are regarded as poor in species richness (e.g., Glanz 1977). Acknowledging the fact that present assemblages are very recent, and have been mostly shaped by humanassociated factors, intercontinental comparisons should include species recently extinct like Octodon bridgesi and Aconaemys fuscus. This long-term perspective should also be applied when population surveys are developed for elaborate evolutionary, conservation, and management analysis.

\section{ACKNOWLEDGMENTS}

This work has been financed by FONDECYT grants 2990120, 1990067, 1990027, 1990049, $1950036,1940106,1921040$. BS is a doctoral fellow of CONICYT.

\section{LITERATURE CITED}

ASCHMANN H (1991) Human impact on the biota of Mediterranean-climate regions of Chile and California. In: Groves RH \& F DI Castri (eds) Biogeography of Mediterranean invasions: 33-41. Cambridge University Press, Cambridge, United Kingdom.

BROWN JH (1984) On the relationship between abundance and distribution of species. American Naturalist 124: 255-279.

CONTRERAS LC, JC TORRES-MURA \& JL YÁÑEZ (1987) Biogeography of Octodontid rodents: an eco-evolutionary hypothesis. In: Patterson BD \& RM Timm (eds) Studies in Neotropical mammalogy: essays in honor of Philip Hershkovitz: 401-411. Fieldiana: Zoology, New Series 39. 
DÍAZ IA, C SARMIENTO, L ULLOA, R MOREIRA, R NAVIA, E VÉLIZ \& C PEÑA (2002) Vertebrados terrestres de la Reserva Nacional Río Clarillo, Chile central: representatividad y conservación. Revista Chilena de Historia Natural 75: 433-448.

GAETE N \& R SÁNCHEZ (1993) Cerro Las Conchas: segundo asentamiento Arcaico. Museos (Chile) 17: 7-8.

GAETE N, R SÁNCHEZ, S CUMSILLE \& C MASSONE (1992) Arqueología al sur del Maule. Museos (Chile) 13: 6-9.

GALLARDO MH \& JAW KIRSCH (2001) Molecular relationships among Octodontidae (Mammalia: Rodentia: Caviomorpha). Journal of Mammalian Evolution 8: 73-89.

GLANZ WE (1977) Small mammal communities from Chile and California. Ph.D. Dissertation, University of California, Berkeley, California, USA. $\mathrm{x}+230 \mathrm{pp}$.

HERMOSILLA N \& B SAAVEDRA (2000) Ocupaciones prehispánicas en la caverna El Carrizo. Actas del XIV Congreso Nacional de Arqueología Chilena Copiapó: 451-472.

HUTTERER R (1994) Island rodents: a new species of Octodon from Isla Mocha, Chile (Mammalia: Octodontidae). Zeitschrift für Säugetierkunde 59: 27-51.

JAKSIC F (1998) Vertebrate invaders and their ecological impacts in Chile. Biodiversity and Conservation 7: 1427-1445.

MANN G (1978) Los pequeños mamíferos de Chile: marsupiales, quirópteros, edentados y roedores. Gayana Zoología (Chile) 40: 1-342.

MESERVE PL, RE MARTIN \& J RODRÍGUEZ (1984) Comparative ecology of the caviomorph rodent Octodon degus in two Chilean Mediterranean-type communities. Revista Chilena de Historia Natural 57: 79-89.

MILLER S (1980) Human influences on the distribution and abundance of wild chilean mammals: prehistoricpresent. Ph.D. Dissertation, University of Washington, Seattle, Washington, USA. v + $431 \mathrm{pp}$

MILLER SD, J ROTTMAN, KJ RAEDEKE \& RD TABER (1983) Endangered mammals of Chile: status and conservation. Biological Conservation 25: 335-352.

MUÑOZ-PEDREROS A (2000) Orden Rodentia. In: MuñozPedreros A \& J Yáñez Valenzuela (eds) Mamíferos de Chile: 73-126. CEA Ediciones, Valdivia, Chile.

PEARSON OP (1995) Annotated keys for identifying small mammals living in or near Nahuel Huapi National Park or Lanín National Park, southern Argentina. Mastozoología Neotropical (Argentina) 2: 99-148.

PLANELLA MT \& B TAGLE (1998) El sitio agroalfarero temprano de La Granja: un aporte desde la perspectiva arqueobotánica. Publicación Ocasional del Museo Nacional de Historia Natural (Chile) 52: 5-64.

PODESTÁ DH, S CIRIGNOLI \& UFJ PARDIÑAS (2000) Nuevos datos sobre la distribución de Octodon bridgesii (Mammalia: Rodentia) en la Argentina. Neotrópica (Argentina) 46: 75-77.

QUIROZ D \& M SÁNCHEZ (1993) Poblaciones tempranas in Isla Mocha (Siglo XIV a.C.). Museos (Chile) 15: $9-11$
REISE D (1973) Clave para la determinación de marsupiales y roedores chilenos. Gayana Zoología (Chile) 27: 1-20

REITZ EJ \& ES WING (1999) Zooarchaeology. Cambridge University Press, Cambridge, United Kingdom. 455 pp.

ROSEN BR (1988) From fossils to Earth history: applied historical biogegraphy. In: Myers AA \& PS Gillier (eds) Applied biogeography: 439-481. Chapman and Hall, London, United Kingdom.

SAAVEDRA B, JA SIMONETTI, C ALDUNATE \& F GALLARDO (1991) Registro arqueozoológico de Octodon (Rodentia) en la costa de Constitución (VII Región, Chile). Medio Ambiente (Chile) 11: 114-117.

SAAVEDRA B, D QUIROZ \& J IRIARTE (2003) Past and present small mammals of Isla Mocha (south-central Chile). Mammalian Biology 68:1-7.

SÁNCHEZ R \& N GAETE (1993) Un asentamiento del Arcaico al sur del Maule. Museos (Chile) 15: 17-19.

SIMONETTI JA (1983) Effect of goats upon native rodents and European rabbits in the Chilean matorral. Revista Chilena de Historia Natural 56: 27-30.

SIMONETTI JA (1989a) Small mammals as paleoenvironmental indicators: validation for species of central Chile. Revista Chilena de Historia Natural 62: 109-114.

SIMONETTI JA (1989b) Sobre la distribución de Aconaemys Ameghino, 1892 en Chile. Noticiario Mensual del Museo Nacional de Historia Natural (Chile) 315: 8-9.

SIMONETTI JA (1994) Impoverishment and nestedness in caviomorph assemblages. Journal of Mammalogy 75: 979-984.

SIMONETTI JA (2000) Paleoecología de mamíferos chilenos. In: Muñoz-Pedreros A \& J Yáñez (eds) Mamíferos de Chile: 229-240. CEA Ediciones, Valdivia, Chile.

SIMONETTI JA \& B SAAVEDRA (1994) Reemplazando espacio por tiempo: arqueofauna del Estero del Manzano. Anales del Museo de Historia Natural de Valparaíso (Chile) 22: 113-119.

SIMONETTI JA \& B SAAVEDRA (1998) Holocene variation in the small mammal fauna of central Chile. Zeitschrift für Säugetierkunde 63: 58-62.

VILLAGRÁN CM (1994) Quaternary history of the Mediterranean vegetation of Chile. In: Kalin MT, P Zedler \& M Fox (eds) Ecology and biogeography of Mediterranean ecosystems in Chile, California and Australia: 3-19. Springer-Verlag, New York, New York, USA.

VILLAGRÁN C \& J VARELA (1990) Palynological evidence for increased aridity on the central Chilean coast during the Holocene. Quaternary Research 34: 198-207.

WEISNER R, M LLAGOSTERA, G CASTILLO \& M CERVELLINO (2000) El sitio arqueológico Huentelauquén en el contexto del Arcaico Temprano de la porción sur del semiárido de Chile. Actas de XIV Congreso Nacional de Arqueología Chilena: 579-620. 